\title{
ENERGY MANAGEMENT SOFTWARE FOR STUDENTS IN ENGINEERING EDUCATION
}

\begin{abstract}
Selçuk ATIŞ̧
Energy demand of a country should be particularly supplied by indigenous energy sources; otherwise, the country would become an energy importing country and dependent on energy-rich countries. In order to benefit from the current renewable energy resources efficiently, many engineers who are specialized on energy management (economic, planning, organization and optimization) are strongly required to be educated with the support of today's advance technology. In this context, various engineering disciplines associated with the concept of energy have been established in many universities around the world as well as in Turkey. In this study, Hybrid Optimization of Multiple Energy Resources (HOMER) software which is very useful for modeling renewable and conventional technologies in various energy management applications and also easy to use, is introduced in detail and presented to today's and future's energy engineers. In order to better understand how the HOMER is efficiently applied, a real-time application for Marmara University Technical Education Faculty which was discussed and is presented in detail.
\end{abstract}

Key words: Renewable energy course, Energy management, Energy system modeling, Engineering education, HOMER

\section{Introduction}

Energy is an important indicator for economic and social development. It is important to use sustainable energy to meet the demand. Yet, most of the energy is produced by unsustainable sources. Turkey is gifted with many indigenous energy resources like wind, solar, geothermal energy etc., but since it has not exploited them so much, it supplies the energy demand by importing fossil based energy sources from some energy rich countries. That is why Turkey is currently an energy dependent country. Figure 1 shows Turkey's gross electricity production according to primary energy resources in 2019 [1].

As a developing country, Turkey's electricity consumption has increased rapidly between 2000 and 2014/10 in conjunction with its fast growing economy and population. While total electricity consumption in 2000 was 98 TWh, in 2013 it raised 198 TWh and also it raised 257 TWh in 2019. Figure 2 shows that electricity consumption of Turkey has increased rapidly after 2000 with the support of the fast growing economy and population $[1,2]$. Furthermore this trend seems to be continuing in the future [3-18]. 2912-9487

${ }^{1}$ Department of Electrical and Energy, University of Marmara, Istanbul, TR, (satis@ marmara.edu.tr) (Dhttps://orcid.org/0000-0002- 


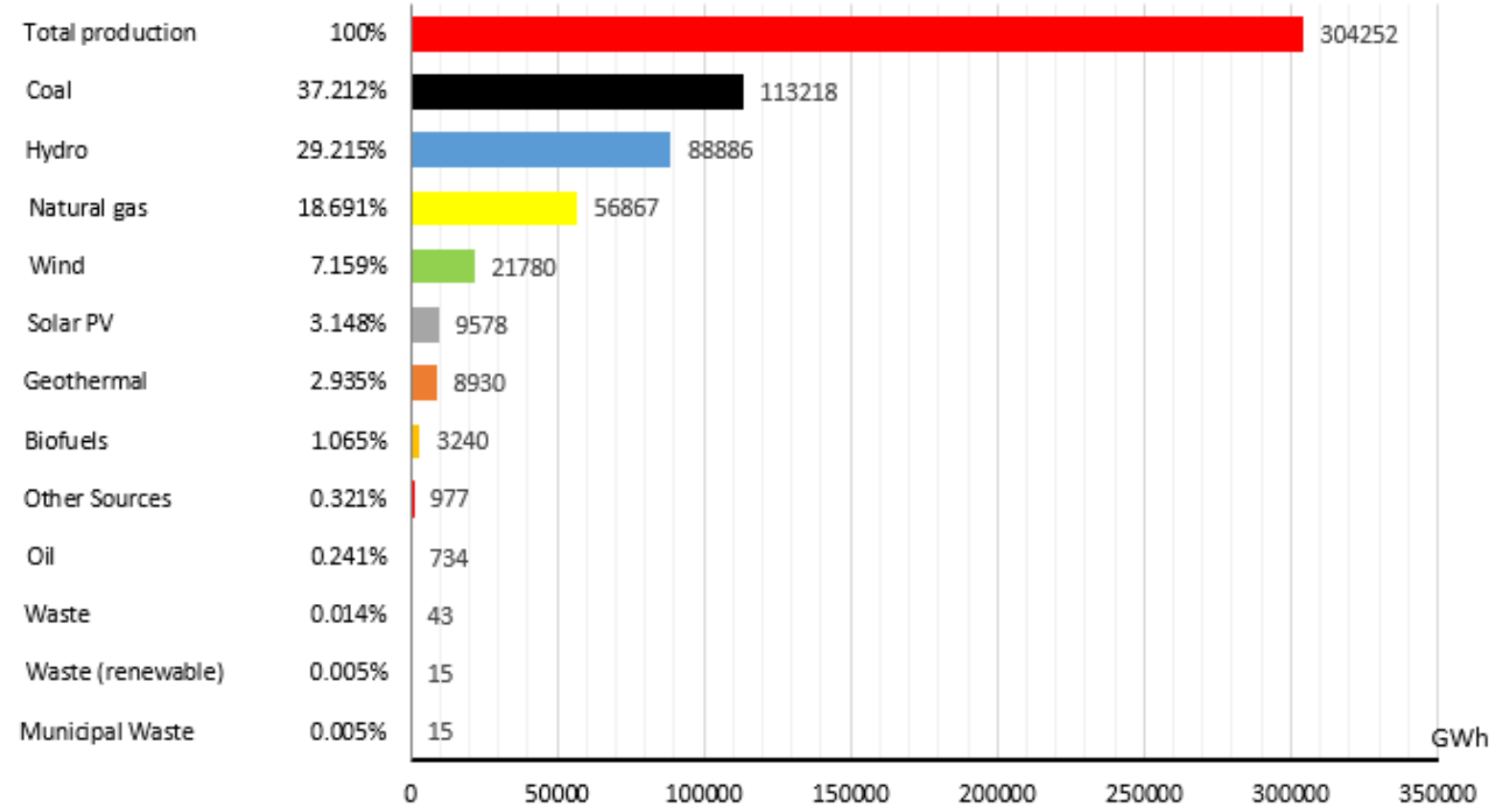

Figure 1. Turkey's gross electricity production according to primary energy resources.

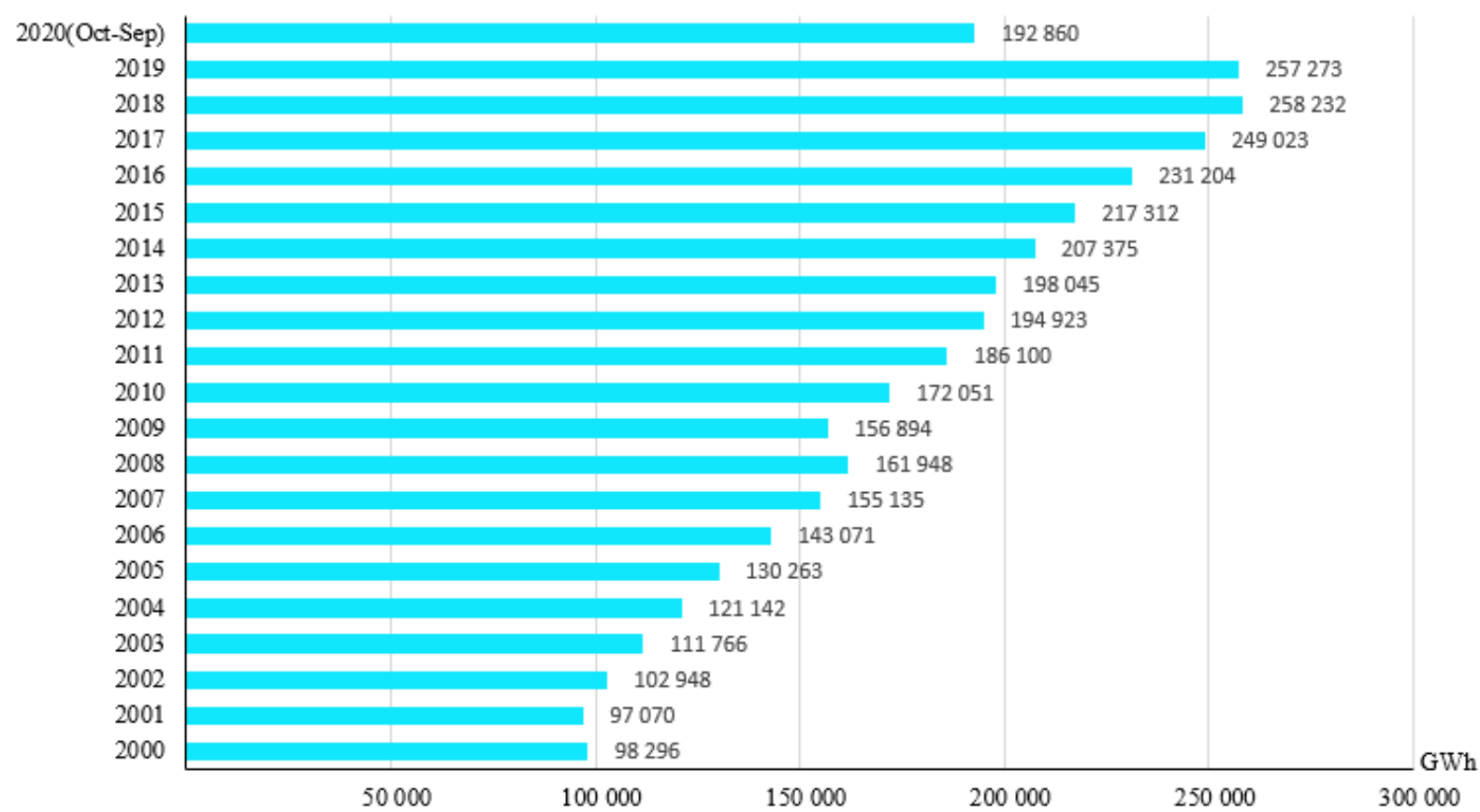

Figure 2. The electricity consumption of Turkey.

Likewise, in Turkey, the laws and the energy politics of the government affect the development of renewable energy. The "National Renewable Energy Action Plan for Turkey", published in 2014, aims energy targets of Turkey in 2023 as below [19]:

- $\quad 30 \%$ of total electricity will be produced by renewable resources

- installed capacity for wind energy will be $20000 \mathrm{MW}$

- installed capacity for solar energy will be ( $\mathrm{min}) 5000 \mathrm{MW}$

- installed capacity for geothermal energy will be $1000 \mathrm{MW}$ 
- the whole economically usable hydropower potential of Turkey will be provided for electricity generation until 2023.

Because of the renewables' variable and instable behavior, only one renewable energy generator cannot continuously supply the demand by itself, and therefore, it is combined with another energy supplier like diesel generator or wind turbine. Besides that, there are some important issues like climate change, security of energy supply, and economic recession based on using conventional energy generating systems. In order to solve these problems renewable energy systems can be used instead of fossil fuel dependent energy systems [20-22]. So, determining the renewable energy potential is very significant for energy planning and optimization. In this context, the application of renewable energy and its effects on other components of the system must be considered. To solve these issues, computer tools are required to perform a techno-economic analysis for defined hybrid energy-systems. There are many computer tools existing in literature which have been applied in many studies. Some of them are summarized as follows. Cormio et al. [21] examined the EFOM energy software, Faraji-Zonooz et al. [23] reviewed the MARKAL energy tool, Ball et al. [24] proposed the MOREHyS energy tool (based on the BALMOREL tool), Tsioliaridou et al. [25] used the Invert energy tool and lastly, Cai et al. [26] proposed the UREM energy tool. The studies are mainly based on the functions of the energy tool and they don't suggest detailed analysis or information about different energy software. There are some more studies analyzing at least two energy tools: Lund et al. [27] compared the two energy tools, Energy PLAN and $\mathrm{H}_{2}$ RES, Morris et al. [28] discussed results of NEMS and MARKAL-MACOR, Segurado et al. [29] examined the EMINENT energy tool with different energy tools (CO2DB, MARKAL, IKARUS, E3database, and Synopsis), and Urban et al. [30] discussed the feasibility of 12 different energy tools for energy-systems of developing countries (including LEAP, MARKAL,MESSAGE, Mini CAM, and RET Screen). Nonetheless these studies do not contain detailed analysis. The unique study comparing various energy tools was made by Jebaraj and Iniyan [31]. In the study they used the models such as supply-demand, forecasting, optimization, neural networks and emission models. However the implementation of each models were not deeply examined [32].

The HOMER software, one of the computer tools used to construct and optimize hybrid power generating systems, belongs to the National Renewable Energy Laboratory (NREL). HOMER is and easy to use software capable of simulating and optimizing the model. Many different kinds of applications can be simulated and analyzed in environmental and techno economical aspect. In Turkey, the HOMER software which is very useful from many aspects aforementioned should be introduced to users related to the concept of energy and of course, involved into the courses at technical universities in order for engineering students both to learn how various energy applications can be performed and to have considerable experiences about the real-world energy management problems and also to be ready as an engineer of future for the tough conditions of the business life [33, 34].

In this study, the HOMER simulation software is introduced in detail and presented to people who are still studying or currently energy engineers. It should be put into the curriculum of the courses in the departments of energy engineering for providing the development of engineering education in Turkish universities. To understand HOMER better and underline that it is easy to learn and use, a simple application for Technical Education Faculty, University of Marmara with a moderate energy demand is considered. The task is modeled step by step and then analyzed by using the HOMER software. 


\section{A Short Overview of Engineering Education in Turkey}

Considering all engineering faculties of Turkey that educate engineers, almost all universities have engineering faculties. However, they offer standard or conventional education to engineers of the future which could not allow them to think like a real engineer when faced some real life problems. Therefore, engineers graduated from those faculties are, in fact, away from engineering mentality. Both to develop the level of the engineering education and also to educate smart engineers who can think analytically and offer practical ideas for some engineering problems, the current engineering education in Turkey must, of course, be supported with advanced technology such as useful engineering software programs that let engineers simulate real life problems, experience some solution ways to the problem and observe their effects on some important parameters as well. Recently energy is very popular concept in the world as well as in Turkey. Turkey has abundance of indigenous energy resources but has many problems dealing with supplying high energy demand [35, 36]. Exploitation of indigenous energy resources in Turkey is currently at the low level; therefore some radical steps should be urgently taken to minimize that problem regarding the current status of higher education:

- New engineering departments (especially energy systems engineering) in many universities should be established and energy engineers should be educated because they are urgently needed to develop the level of exploitation of renewable energy resources.

- Engineering education as well as energy engineering education should be enriched with the contribution of today's advance technology such as engineering software programs, simulation programs, well-equipped workshops, etc.

In this study, HOMER engineering software program, one of the useful ones, is introduced in detail. Furthermore, we think that integration of HOMER software program to the current engineering education in Turkey enables engineer have good experience and equipment for easy-adaptation to tough business life.

\section{Why should the HOMER be in the energy management based engineering education in Turkey?}

The HOMER is very efficient and user friendly program. It is easy to use it as well as to analyze and model energy systems. Furthermore, there are many advantages of HOMER software, which will be mentioned in this section taking three major aspects into consideration; many useful characteristics of HOMER software, education of engineers of future and economical and social development of the country, Turkey. The contributions of the HOMER software to both engineers of future who will be educated in Turkish universities and also Turkey will be determined and expressed here.

The software can be downloaded without any charge and about 120,000 people have been using HOMER so far [37]. HOMER has high reliability and can be used in many applications. Especially, standalone and grid connected systems consisting of combinations of PV panels, fuel cells, biomass,etc. can be modelled and analyzed by the users in HOMER. The software calculates all costs excluding cost of fuel handling and taxes. Standalone and grid connected systems consisting of combinations of PV panels, fuel cells, biomass, etc. can be modelled and analyzed by the users in HOMER. The software calculates all costs excluding cost of fuel handling and taxes. The simulation aims to investigate the techno-economic optimization of quantity of system components considering the cost and availability of the resource. 
Students will have energy management problem solving opportunities through the HOMER software program which are effectively and simply applied for simulations of various energy management problems. So, they will gain great experiences for solving complex problems they may probably have in future. After a well-engineering education which is supported by more practicing with computer software programs like the HOMER software and workshop works, engineers will be much more ready for the tough conditions of the business life because they are well-equipped with some necessary qualifications such as, technical information, experience, well-practicing, application skills.

As a developing country, Turkey should efficiently exploit available abundant energy potential, which is mentioned in detail in the previous sections. That is why Turkey urgently needs well-equipped engineers who know energy planning, modeling and optimization to make the energy production more possible and efficient. Providing energy production from domestic sources with the supports of native, smart and skillful engineers will seriously contribute to achieve Turkey's energy independence. So, Turkey will not both import much more energy from some countries and also pay billions of dollars for meeting the energy demand any more. Turkey will not need to import skillful and smart engineers from countries for big energy projects anymore because it will be able to educate them in universities itself, providing the integration of today's new technologies into the engineering education.

\section{The HOMER Software as an Educational Energy Modeling Tool}

\subsection{Overview of the HOMER Software}

HOMER is a user-friendly micro power design tool developed in 1992 by the NREL in the USA. It allows to design energy systems containing both standalone and grid connected. By means of optimization and sensitivity analysis algorithm of HOMER, users can investigate techno-economical suitability of the quantity of the resources and calculate the costs potential of energy sources and other variables [37].

\subsection{Loads, Components, and Resources in HOMER Software}

In HOMER software there must be at least energy sources such as wind turbine, diesel generator, etc. and load such as thermal or electrical load. Additionally, converters (DC-AC, AC-DC, Electrolyzer) and energy storage devices such as batteries and hydrogen storage can be used in the design of the system. Only four types of renewable energy sources (solar, hydro, biomass and wind) can be used in the software. Alternatively, Fuel cell and diesel generator can also be utilized. Energy production of renewable energy sources depends on the geographic and climate conditions of the place. It is directly related with the quantity of components of the renewable energy sources estimated by HOMER software [33].

HOMER takes care of ten types of components in the system modeling. Three of them called as photovoltaic modules, wind turbines, and hydro turbines generate electricity from intermittent renewable sources. Other three types of components, namely, generators, the grid, and boilers, are dispatchable energy sources, which means, when needed, they are controlled by the system. Two types of components, converters and electrolyzers, change the form of the electrical energy from AC to DC or from DC to AC. Hydrogen storage tanks and batteries are devices used to store energy. While batteries store dc electric, hydrogen tanks store hydrogen obtained from the electrolyzer and supply fuel to generators. 


\subsection{Overall Analysis in HOMER Software}

Three principal tasks; simulation, optimization, and sensitivity analysis, are performed in HOMER. In the simulation process, for each hour of the year HOMER models the performance of a particular power system configuration considering its technical feasibility and life-cycle cost. In the optimization process, HOMER simulates many different system configurations and tries to find the one that satisfies the technical constraints at the lowest life-cycle cost. In the sensitivity analysis process, HOMER makes multiple optimizations under some assumptions in order to have information about the vague or variances in the model input values. Figure 3 demonstrates the relation between simulation, optimization, and sensitivity analysis. Similarly, the sensitivity analysis oval encloses the optimization oval because a single sensitivity analysis consists of many optimizations.

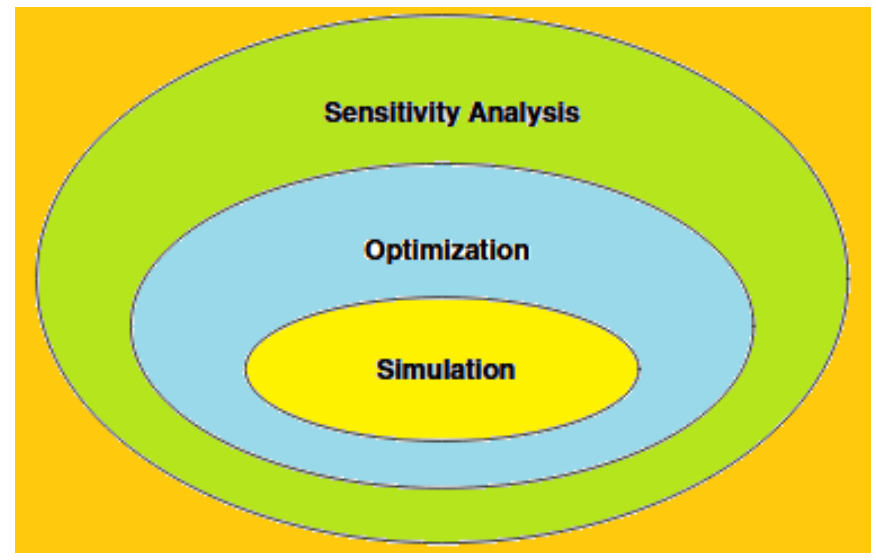

Figure 3. Conceptual relationship between simulation, optimization, and sensitivity analysis.

\subsubsection{Simulation Process in HOMER}

Many different system configurations can be simulated in HOMER. The system can include PV modules, hydro turbine, wind turbines, batteries, generators, converters, hydrogen storage tank and electrolyzer. The simulated system can be grid connected or standalone and can meet the loads of ac, dc or thermal load.

Systems containing a battery bank and one or more generators require a dispatch strategy which charges the batteries in the system. In HOMER there are two strategies one of which is load following and the other is cycle charging. In the load following strategy renewable energy sources charge the battery while generators do not. In the cycle charging strategy, the generators produce more energy than needed which meets the demand and also charges the batteries.

In the simulation process two targets can be achieved. First, the most suitable system can be determined. Second, life-cycle and cost of the system including capital and operational cost can be calculated [33].

\subsubsection{Sensitivity analysis in HOMER}

A sensitivity analysis indicates how the output values change in terms of the variance of the input values. The user can enter multiple values for a variable in the sensitivity analysis and therefore it can be called as sensitivity variable. Grid power and fuel prices, lifetime of wind turbine and load can be examples for sensitivity variables. 


\section{An Application for Marmara University Faculty of Technical Education}

In this section, an application is performed to better explain how to use the HOMER software. In the application, it is aimed both to supply all the energy demand of Faculty of Technical Education in Marmara University with the available regional renewable energy sources (solar and wind energy) instead of the grid and also to determine the economic and best one among all possible system configurations. Thus, the electricity generated in this way will be more sensitive to the environment. Main components of the system are shown in Figure 4.

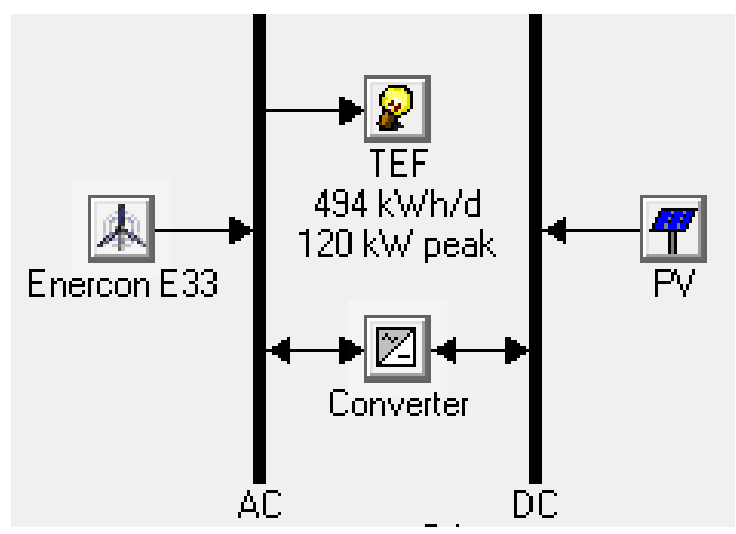

Figure 4. Hybrid system components.

Energy demand of the campus is currently met by electricity grid. Data of the load is received from AYEDAS. As seen in Fig. 5, the peak value of the load is $120 \mathrm{~kW}$ while average daily load demand is $494 \mathrm{~kW}[38,39]$.

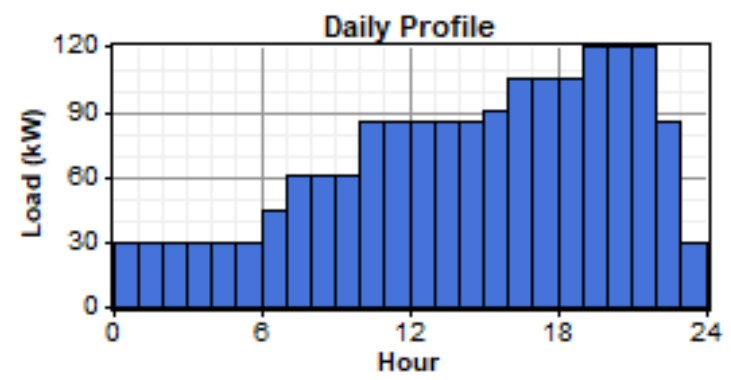

Figure 5. Daily load profile of the faculty.

Solar radiation data of the location was received from Turkish State Meteorological Service (TSMS) in 2017 [40]. Annual average solar energy density is estimated to be $4.98 \mathrm{kWhm}^{-2} \mathrm{~d}^{-1}$. The hourly wind speed data of the location was measured at $10 \mathrm{~m}$ altitude and the data was obtained from the Turkish Metrological Department. As seen from the wind speed data, the wind speed distribution varies between $4.26 \mathrm{~m} / \mathrm{s}$ and $6.27 \mathrm{~m} / \mathrm{s}$ and the locational average wind speed is about $5.208 \mathrm{~m} / \mathrm{s}$.

Table 1. System components considered.

\begin{tabular}{|c|c|c|c|c|c|}
\hline Component & Size & $\begin{array}{c}\text { Capital Cost } \\
(\$ / \mathbf{k W h}) \\
\end{array}$ & $\begin{array}{c}\text { Replacement cost } \\
(\$ / \mathbf{k W h})\end{array}$ & $\begin{array}{c}\text { O\&M Cost } \\
(\$ / y r) \\
\end{array}$ & Lifetime \\
\hline PV Panels & $0-1000 \mathrm{~kW}$ & $2800 \$ / \mathrm{kWh}$ & $2800 \$ / \mathrm{kWh}$ & $200 \$ / y r$ & $15 \mathrm{yr}$ \\
\hline Enercon WT & $0-1320 \mathrm{~kW}$ & $1500 \$ / \mathrm{kWh}$ & $1500 \$ / \mathrm{kWh}$ & $350 \$ / y r$ & $15 \mathrm{yr}$ \\
\hline Converter & $0-250 \mathrm{~kW}$ & $900 \$ / \mathrm{kWh}$ & $900 \$ / \mathrm{kWh}$ & $100 \$ / y r$ & $15 \mathrm{yr}$ \\
\hline Battery & $0-500$ pieces & $300 \$$ & $300 \$$ & 0.010 & $15 \mathrm{yr}$ \\
\hline
\end{tabular}


The search space, list of the system component and size that HOMER considered for this analysis are shown in Table 1. Standalone power generating system that allows supplying all of the electricity demand from renewable energy sources includes main components such as converter, load, PV panel, wind turbine and battery. System construction or arrangement of the components in the system is can be seen in Figure 6.

\begin{tabular}{|c|c|c|c|c|}
\hline & PV Array & FL250 & S4KS25P & Converter \\
\hline & (kw) & [Quantity] & [Quantity] & (kW] \\
\hline 1 & 0.000 & 0 & 0 & 0.00 \\
\hline 2 & 120.000 & 1 & 100 & 120.00 \\
\hline 3 & 240.000 & 2 & 300 & \\
\hline 4 & 360.000 & 3 & 600 & \\
\hline 5 & 480.000 & 4 & 800 & \\
\hline 6 & & & & \\
\hline 7 & & & & \\
\hline 8 & & & & \\
\hline 9 & & & & \\
\hline 10 & & & & \\
\hline
\end{tabular}

Figure 6. The possible sizes of each component of the standalone power generating system.

The user would not know the quantity of wind turbines, PV panels, batteries, and size of converter in advance. Hence, these four variable sources are decision variables in sensitivity analysis. The In HOMER, different values for each variable can be defined to observe the effects of the interested variable on the system outputs like net present cost and cost of energy. Figure 6 includes a table including different amount of the components which was simulated through the HOMER. For example, five different values of the PV array, ranging from 0 to $480 \mathrm{~kW}$; five different quantities of the wind turbine, ranging from 0 to 4; five different quantities of the battery, ranging from to 0 to 800 ; and two different values for the converter, ranging from 0 to $120 \mathrm{~kW}$, are specified in the HOMER software for making a comprehensive analysis of all possible system configurations and determining the best one regarding some economic parameters (Cost of energy, net present cost). The search space of the proposed system comprises of 250 different types of system configurations which is the result of the multiplication of the quantity of the components such as wind turbines, PV Panels, converters and batteries. In sensitivity analysis HOMER lists optimum systems in table according to total net present cost.

Figure 7 illustrates the consequences of the standalone power generating system analysis. Feasible system configurations are represented in each row in Figure 7. Columns in Figure 7 are called as follows;

- First two column show sensitivity variables such as solar radiation and wind speed.

- Between the third and the sixth columns demonstrate the types of utilized energy system.

- From the seventh to the tenth column illustrate the amount of the utilized energy systems.

- Initial capital, operating cost, total net present cost and cost of energy are shown between the eleventh and the fourteenth columns respectively.

- In the last three columns Renewable fraction, capacity shortage and battery lifetime can be seen.

According to Figure 7, it can be seen that the first row is estimated to be the optimum configuration by means of current solar radiation and wind speed data. The optimum system includes 300 batteries, $120 \mathrm{~kW}$ converter and $250 \mathrm{~kW}$ wind turbine. It is also possible in HOMER software to filter the results according to the least cost configuration. The least cost configuration of Figure 7 is the standalone Wind-Battery system [39,41]. The system configuration has capital cost of $\$ 343,600$ and cost of energy of $\$ 0.217$ per $\mathrm{kWh}$. 


\begin{tabular}{|c|c|c|c|c|c|c|c|c|c|c|c|c|c|}
\hline $\begin{array}{c}\text { Solar } \\
\left(\mathrm{kWh} / \mathrm{m}^{2} / \mathrm{d}\right)\end{array}$ & $\begin{array}{l}\text { Wind } \\
(\mathrm{m} / \mathrm{s})\end{array}$ & 甲 & $\begin{array}{c}\text { PV } \\
(\mathrm{kW})\end{array}$ & FL250 & S4KS25P & $\begin{array}{l}\text { Conv. } \\
(\mathrm{kW})\end{array}$ & $\begin{array}{c}\text { Initial } \\
\text { Capital } \\
\end{array}$ & $\begin{array}{l}\text { Operating } \\
\text { Cost }(\mathrm{s} / \mathrm{yr}) \\
\end{array}$ & $\begin{array}{l}\text { Total } \\
\text { NPC }\end{array}$ & \begin{tabular}{|c|}
$\mathrm{COE}$ \\
$(\mathrm{s} / \mathrm{kWh})$ \\
\end{tabular} & $\begin{array}{l}\text { Ren. } \\
\text { Frac. }\end{array}$ & \begin{tabular}{|l|} 
Capacity \\
Shortage
\end{tabular} & $\begin{array}{c}\text { Batt. Lf. } \\
(\mathrm{yr})\end{array}$ \\
\hline 4.028 & 5.208 & L 8 & & 1 & 300 & 120 & $\$ 343,600$ & 10,044 & $\$ 472,001$ & 0.217 & 1.00 & 0.07 & 12.0 \\
\hline 4.028 & 4.500 & 2. & & 2 & 300 & 120 & $\$ 518,600$ & 14,312 & $\$ 701.556$ & 0.316 & 1.00 & 0.05 & 12.0 \\
\hline 4.028 & 5.000 & 1. 图 & & 1 & 300 & 120 & $\$ 343,600$ & 10,044 & $\$ 472,001$ & 0.220 & 1.00 & 0.09 & 12.0 \\
\hline 4.028 & 6.000 & 1.图 & & 1 & 100 & 120 & $\$ 283,600$ & 7.555 & $\$ 380,179$ & 0.175 & 1.00 & 0.08 & 12.0 \\
\hline 4.028 & 7.000 & 1. 图 & & 1 & 100 & 120 & $\$ 283,600$ & 7.555 & $\$ 380,179$ & 0.170 & 1.00 & 0.04 & 12.0 \\
\hline 4.028 & 3.000 & 1. 图 & 120 & 3 & 600 & 120 & $\$ 1,107,600$ & 26,970 & $\$ 1,452,366$ & 0.681 & 1.00 & 0.10 & 12.0 \\
\hline 5.000 & 5.208 & 10 & & 1 & 300 & 120 & $\$ 343,600$ & 10,044 & $\$ 472,001$ & 0.217 & 1.00 & 0.07 & 12.0 \\
\hline 5.000 & 4.500 & 1. 圈 & & 2 & 300 & 120 & $\$ 518,600$ & 14,312 & $\$ 701,556$ & 0.316 & 1.00 & 0.05 & 12.0 \\
\hline 5.000 & 5.000 & 1. 图 & & 1 & 300 & 120 & $\$ 343,600$ & 10,044 & $\$ 472,001$ & 0.220 & 1.00 & 0.09 & 12.0 \\
\hline 5.000 & 6.000 & 1. 图 & & 1 & 100 & 120 & $\$ 283,600$ & 7.555 & \$ 380.179 & 0.175 & 1.00 & 0.08 & 12.0 \\
\hline 5.000 & 7.000 & 1. 图 & & 1 & 100 & 120 & $\$ 283,600$ & 7.555 & $\$ 380.179$ & 0.170 & 1.00 & 0.04 & 12.0 \\
\hline 5.000 & 3.000 & 10 & 120 & 3 & 600 & 120 & $\$ 1,107,600$ & 26.970 & $\$ 1,452,366$ & 0.672 & 1.00 & 0.08 & 12.0 \\
\hline 6.000 & 5.208 & 1. & & 1 & 300 & 120 & $\$ 343,600$ & 10,044 & $\$ 472,001$ & 0.217 & 1.00 & 0.07 & 12.0 \\
\hline 6.000 & 4.500 & 1. & & 2 & 300 & 120 & $\$ 518,600$ & 14,312 & $\$ 701,556$ & 0.316 & 1.00 & 0.05 & 12.0 \\
\hline 6.000 & 5.000 & 1. 图 & & 1 & 300 & 120 & $\$ 343,600$ & 10,044 & $\$ 472,001$ & 0.220 & 1.00 & 0.09 & 12.0 \\
\hline 6.000 & 6.000 & 1. & & 1 & 100 & 120 & $\$ 283,600$ & 7,555 & $\$ 380,179$ & 0.175 & 1.00 & 0.08 & 12.0 \\
\hline 6.000 & 7.000 & 图 & & 1 & 100 & 120 & $\$ 283,600$ & 7.555 & \$ 380,179 & 0.170 & 1.00 & 0.04 & 12.0 \\
\hline 6.000 & 3.000 & $\theta$ & 120 & 3 & 600 & 120 & $\$ 1,107,600$ & 26.970 & $\$ 1,452,366$ & 0.668 & 1.00 & 0.07 & 12.0 \\
\hline 7.000 & 5.208 & 图 & & 1 & 300 & 120 & $\$ 343,600$ & 10,044 & $\$ 472,001$ & 0.217 & 1.00 & 0.07 & 12.0 \\
\hline 7.000 & 4.500 & 1. & & 2 & 300 & 120 & $\$ 518,600$ & 14,312 & $\$ 701,556$ & 0.316 & 1.00 & 0.05 & 12.0 \\
\hline 7.000 & 5.000 & 1. $\square$ & & 1 & 300 & 120 & $\$ 343,600$ & 10,044 & $\$ 472,001$ & 0.220 & 1.00 & 0.09 & 12.0 \\
\hline 7.000 & 6.000 & 1. $\nabla$ & & 1 & 100 & 120 & $\$ 283,600$ & 7.555 & $\$ 380,179$ & 0.175 & 1.00 & 0.08 & 12.0 \\
\hline 7.000 & 7.000 & $1 \%$ & & 1 & 100 & 120 & $\$ 283,600$ & 7,555 & $\$ 380,179$ & 0.170 & 1.00 & 0.04 & 12.0 \\
\hline 7.000 & 3.000 & 1 & 120 & 3 & 300 & 120 & $\$ 1,017,600$ & 23,236 & $\$ 1,314,633$ & 0.618 & 1.00 & 0.10 & 12.0 \\
\hline 3.000 & 5.208 & 从国 & & 1 & 300 & 120 & $\$ 343,600$ & 10,044 & $\$ 472,001$ & 0.217 & 1.00 & 0.07 & 12.0 \\
\hline
\end{tabular}

Figure 7. The categorized optimization of all results.

Added to this, the second ranked Figure 8 system in is the least cost configuration for the standalone PV-Wind-Battery system category, including one wind turbine, the $120 \mathrm{~kW}$ PV panel, 100 batteries, and a $120 \mathrm{~kW}$ converter. Also, the standalone PV-Wind-Battery system with optimal configuration has the initial investment of $\$ 607,600$ and the cost of energy of $0.356 \$ / \mathrm{kWh}$. But, when focused on the cost of energy values for the two possible power generating system categories in Figure 7 , one of the very important parameters in the determination of the best or optimal configuration for any power generating system category, it is easily realized that the standalone Wind-battery system with optimal configuration is more applicable and reasonable due to the fact that it has the least cost of energy and the least total net present cost and the least capital. Furthermore, one of the obtained results is that for the standalone PV-Wind-Battery system with optimal configuration, the $120 \mathrm{~kW} \mathrm{PV}$ panel and one wind turbine suffices with no contribution of wind turbines to the system.

\begin{tabular}{|c|c|c|c|c|c|c|c|c|c|c|c|}
\hline 雨 & $\begin{array}{l}\text { PV } \\
(\mathrm{kW})\end{array}$ & FL250 & S4KS25P & $\begin{array}{l}\text { Conv. } \\
(\mathrm{kW})\end{array}$ & $\begin{array}{l}\text { Initial } \\
\text { Capital }\end{array}$ & $\begin{array}{c}\text { Operating } \\
\text { Cost (\$/yr) }\end{array}$ & $\begin{array}{l}\text { Total } \\
\text { NPC }\end{array}$ & $\begin{array}{c}\mathrm{COE} \\
(\mathrm{S} / \mathrm{kWh})\end{array}$ & $\begin{array}{l}\text { Ren. } \\
\text { Frac. }\end{array}$ & $\begin{array}{l}\text { Capacity } \\
\text { Shortage }\end{array}$ & $\begin{array}{c}\text { Batt. Lf } \\
\text { (yr) }\end{array}$ \\
\hline & & 1 & 300 & 120 & & 10,044 & $\$ 472$. & 0.217 & 1.00 & 0.07 & 12.0 \\
\hline & 120 & 1 & 100 & 120 & $\$ 607,600$ & 12,211 & \$ 763,701 & 0.356 & 1.00 & 0.09 & 12.0 \\
\hline
\end{tabular}

Figure 8. Categorized optimization results.

\section{Conclusions}

In summary, the HOMER software program should be certainly involved in the engineering departments at the Turkish Universities due to the following reasons as mentioned in the previous sections.

- It is simple and easy to learn and use, such that a typical analysis by the HOMER can be made in a short time learning facility. 
- In HOMER traditional and renewable technologies can be modelled with real world limits and the result can be achieved easily.

- Standalone and grid connected systems consisting of combinations of PV panels, fuel cells, biomass, etc. can be modelled and analyzed by the users in HOMER. The software calculates all costs excluding cost of fuel handling and taxes.

- Students will have energy management problem solving opportunities through the HOMER software program which are effectively and simply applied for simulations of various energy management problems. So, they will gain great experiences for solving complex problems they may probably have in future.

- Many different situations and conditions can be calculated and analyzed

- Turkish engineers will be much more ready for the tough conditions of the business life because they are well-equipped with some required qualifications such as, technical information, experience, well-practicing, application skills etc.

- As a developing country, Turkey should efficiently exploit its own available rich energy potential. That is why Turkey urgently needs well-equipped engineers who know energy planning, modeling and optimization to make the energy production from those sources more possible and efficient. In addition, providing energy production from domestic sources with the supports of native, smart and skillful engineers will seriously contribute to achieve Turkey's energy independence. So, Turkey will not both import much more energy from some countries and also pay billions of dollars for meeting the energy demand any more. Furthermore, Turkey will not need to import skillful and smart engineers from countries for big energy projects anymore because it will be able to educate them at the universities itself, providing the integration of new technological developments into the engineering education.

- To understand how to use HOMER better, a simple application for the campus, with a moderate energy demand is considered. The task is modeled step by step and then analyzed by using the HOMER software to determine the followings.

$\circ$ the optimum configuration of a standalone hybrid energy system including any combination of wind turbines, PV panels a converter and batteries and

o the behavior of the economical parameters such as NPC and COE for various system configurations with different size or quantity of components.

\section{References}

[1] International Energy Agency, https://www.iea.org, 01.12.2020.

[2] Tetc Electricity Generation - Transmission Statistics of Turkey, https://www.teias.gov.tr, December 2020.

[3] Akar, O., Terzi, Ü.K., Tunçalp, B.K., and Sönmezocak, T. (2019). Determination of the Optimum Hybrid Renewable Power System: A Case Study of Istanbul Gedik University Gedik Vocational School. Balkan Journal of Electrical and Computer Engineering, 7(4), pp. 456-463.

[4] Dawood, K. (2016). Hybrid Wind-Solar Reliable Solution for Turkey to Meet Electric Demand. Balkan Journal of Electrical and Computer Engineering, 4(2), pp. 62-66.

[5] Erken, F. (2020). The Impact of the Government's Incentives on Increasing Investment in Turkey's Solar Photovoltaic Power Plants. Balkan Journal of Electrical and Computer Engineering, 8(1), pp. 40-49. 
[6] Kentli, F., \& Yilmaz, M. (2017). Improving Tracking Efficiency of Two-Axis Sun Tracking Systems. In Energy Harvesting and Energy Efficiency (pp. 179-203). Springer, Cham.

[7] Vedat, E., Neşe, S.V., Saglam, Ş., and Oral, B. (2016). The Training of Renewable Energy Systems Undergraduate Studies. Balkan Journal of Electrical and Computer Engineering, 5(1), pp. 26-29.

[8] Yüksel, O., Şahin, M., and Güven, Y. (2015). Importance of Solar Lighting Systems in Terms of Environmental Pollution. Balkan Journal of Electrical and Computer Engineering, 3(4), pp. 208-212.

[9] Başoğlu, M.E. and Çakir, B. (2015). Wind Energy Status in Turkey. International Journal of Environmental, Ecological, Geological and Geophysical Engineering, 9(1), pp. 19-24.

[10] Yilmaz, M. (2018). Real measure of a transmission line data with load fore-cast model for the future. Balkan Journal of Electrical and Computer Engineering, 6(2), 141-145.

[11] Çiçek, O., Millad, M.A.M., and Erken, F. (2019). Energy Prediction Based on Modelling and Simulation Analysis of an Actual Grid-Connected Photovoltaic Power Plant in Turkey. European Journal of Technique, 9(2), pp. 159-174.

[12] Koçyiğit, F. (2019). The Evaluating of Wind Energy Potential of Diyarbakır Using Weibul and Rayleigh Distribution. European Journal of Technique, 9(1), pp. 99-113.

[13] Ekren, N., Onat, N., and Saglam, S. (2008). Household Type Load's Effects on Photovoltaic Systems. WSEAS Transactions on Circuits and Systems, 7(12), pp. 1020-1028.

[14] Ekren, N. and Gorgulu, S. (2012). An Investigation into the Usability of Straight Light-Pipes in Istanbul. Energy Educ. Sci. Technol. Part A, 30(1), pp. 637-644.

[15] Ersoz, S., Akinci, T.C., Nogay, H.S., and Dogan, G. (2013). Determination of Wind Energy Potential in Kirklareli-Turkey. International Journal of Green Energy, 10(1), pp. 103-116.

[16] Akinci, T.C., Seker, S., Akgun, O., Dikun, J., and Erdemir, G. (2017). Bispectrum and Energy Analysis of Wind Speed Data. International Journal of Electrical Energy, 5(1), pp. 87-91.

[17] Y1lmaz, M. and Kentli, F. (2015). Increasing of Electrical Energy with Solar Tracking System at the Region Which Has Turkey's Most Solar Energy Potential. Journal of Clean Energy Technologies, 3(4), pp. 287-290.

[18] Akkılıç, K., Ocak, Y. S., \& Yılmaz, M. (2015). Analysing enhancement of electricity generating capacity with solar tracking system of the most sunning region of Turkey. Journal of Clean Energy Technologies, 3(4), 291-295.

[19] National Renewable Energy Action Plan for Turkey, Republic of Turkey Ministry of Energy and Natural Resources, December 2014.

[20] Celiktas, M.S. and Kocar, G. (2009). A Quadratic Helix Approach to Evaluate the Turkish Renewable Energies. Energy Policy, 37(11), pp. 4959-4965.

[21] Cormio, C., Dicorato, M., Minoia, A., and Trovato, M. (2003). A Regional Energy Planning Methodology Including Renewable Energy Sources and Environmental Constraints. Renewable and Sustainable Energy Reviews, 7(2), pp. 99-130.

[22] Birol, F., World Energy Outlook 2013, International Energy Agency Paris, 2013.

[23] Zonooz, M.R.F., Nopiah, Z.M., Yusof, A.M., and Sopian, K. (2009). A Review of Markal Energy Modeling. European Journal of Scientific Research, 26(3), pp. 352-361.

[24] Ball, M., Wietschel, M., and Rentz, O. (2007). Integration of a Hydrogen Economy into the German Energy System: An Optimising Modelling Approach. International Journal of Hydrogen Energy, 32(10-11), pp. 1355-1368.

[25] Tsioliaridou, E., Bakos, G.C., and Stadler, M. (2006). A New Energy Planning Methodology for the Penetration of Renewable Energy Technologies in Electricity Sector-Application for the Island of Crete. Energy Policy, 34(18), pp. 3757-3764. 
[26] Cai, Y.P., Huang, G.H., Lin, Q.G., Nie, X.H., and Tan, Q. (2009). An Optimization-Model-Based Interactive Decision Support System for Regional Energy Management Systems Planning under Uncertainty. Expert Systems with Applications, 36(2), pp. 3470-3482.

[27] Lund, H., Duić, N., Krajac, G., and da Graca Carvalho, M. (2007). Two Energy System Analysis Models: A Comparison of Methodologies and Results. Energy, 32(6), pp. 948-954.

[28] Morris, S.C., Goldstein, G.A., and Fthenakis, V.M. (2002). Nems and Markal-Macro Models for Energy-Environmental-Economic Analysis: A Comparison of the Electricity and Carbon Reduction Projections. Environmental Modeling \& Assessment, 7(3), pp. 207-216.

[29] Segurado, R., Pereira, S., Pipio, A., and Alves, L. (2009). Comparison between Eminent and Other Energy Technology Assessment Tools. Journal of Cleaner Production, 17(10), pp. $907-$ 910.

[30] Urban, F., Benders, R.M.J., and Moll, H.C. (2007). Modelling Energy Systems for Developing Countries. Energy Policy, 35(6), pp. 3473-3482.

[31] Jebaraj, S. and Iniyan, S. (2006). A Review of Energy Models. Renewable and Sustainable Energy Reviews, 10(4), pp. 281-311.

[32] Connolly, D., Lund, H., Mathiesen, B.V., and Leahy, M. (2010). A Review of Computer Tools for Analysing the Integration of Renewable Energy into Various Energy Systems. Applied energy, 87(4), pp. 1059-1082.

[33] Lambert, T., Gilman, P., and Lilienthal, P. (2006). Micropower System Modeling with Homer. Integration of alternative sources of energy, 1(1), pp. 379-385.

[34] Aykut, E. and Terzi, Ü.K. (2020). Techno-Economic and Environmental Analysis of Grid Connected Hybrid Wind/Photovoltaic/Biomass System for Marmara University Goztepe Campus. International Journal of Green Energy, 17(15), pp. 1036-1043.

[35] Karabulut, A., Gedik, E., Keçebaş, A., and Alkan, M.A. (2011). An Investigation on Renewable Energy Education at the University Level in Turkey. Renewable Energy, 36(4), pp. 1293-1297.

[36] Bojic, M. (2004). Education and Training in Renewable Energy Sources in Serbia and Montenegro. Renewable Energy, 29(10), pp. 1631-1642.

[37] Homer Energy, https://www.homerenergy.com/, 2020.

[38] Dursun, B. (2015). Determination of Optimum Renewable Energy Sources for Public Libraries. Balkan Journal of Electrical and Computer Engineering, 3(2), pp. 70-73.

[39] Gokcol, C. and Dursun, B. (2011). Determination of the Optimum Renewable Power Generating Systems for an Educational Campus in Kirklareli University. Ejovoc (Electronic Journal of Vocational Colleges), 1(1), pp. 8-17.

[40] Turkish State Meteorological Service, https://mgm.gov.tr, 2017.

[41] Dursun, B. and Gokcol, C. (2014). Impacts of the Renewable Energy Law on the Developments of Wind Energy in Turkey. Renewable and Sustainable Energy Reviews, 40(1), pp. 318-325. 